\title{
Obituary
}

\section{Tribute to Hari Saran Nepali (1943 - 2021 AD)}

\section{Tej Bahadur Thapa*}

Central Department of Zoology, Institute of Science and Technology, Tribhuvan University,

Kathmandu, Nepal

*Correspondence: tej.thapa@cdz.tu.edu.np

It is with profound grief that we remember Mr. Hari Saran Nepali, who left for his heavenly abode on May 2021. Late Hari Saran Nepali, who died at the age of 87 , belonged to the generation of ornithologists who did so much to collect bird specimens and popularize birdwatching in Nepal. Naturalists, conservationists and zoologists as well as many other peoples in Nepal and abroad were extremely saddened to hear the death of Hari Saran. He made significant contribution in developing the knowledge of the birdlife of Nepal. His work was noteworthy for its comprehensiveness and the sheer length of time he devoted. Almost six decades of self-study and extensive visits throughout the country has made, Hari Saran familiar with most of the bird species of Nepal. His passion, devotion and dedication to birds and nature, allowed him to record and collect specimens of many species of Nepali birds. Noteworthy, Hari Saran's accomplishments in the field of ornithology was more unusual in that, he was completely self-taught on bird's behavior, call, topography and systematics as well as collection and preservation techniques. $\mathrm{He}$ has deep understanding the value of natural history collections and his data collection was meticulous.

His interest on birdlife went back to his teen age, when he used to accompany his father on hunting trips and started to keep notes on birds. Since early 1950s, Hari Sharan started observation in the wild and taking notes of habitats, migration patterns, behavior, colour and plumage characteristics of the birds. He began a systematic record keeping, collection and preservation of specimens in 1950s. His field recordings and specimens that he has collected from the different parts of the country are major components of the bird specimens in the Central Department of Zoology Museum and Natural History Museum, Tribhuvan University.

Hari Saran Nepali has worked at the Central Department of Zoology, Tribhuvan University as in- charge of fauna collection from 1971 to 1974. At the Central Department of Zoology, Hari Saran has

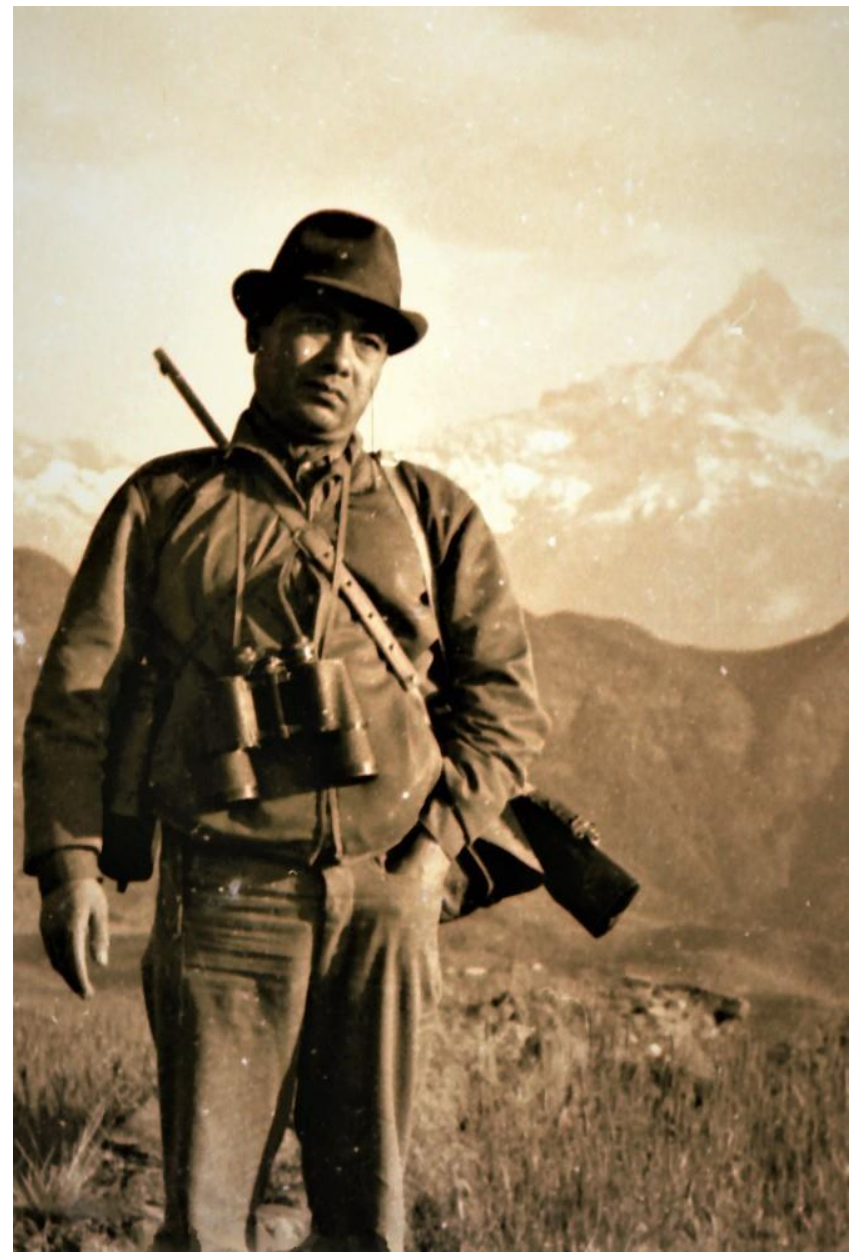

Photo 1: Hari Saran Nepali during a field expedition at Naudada, Pokhara in 1972 (Source: Prof. Dr. Parasar Narayan Suwal 
collected and deposited around 300 specimens mainly of birds and some of Mammals. All these specimens are preserved and available for studies.

Later, Hari Saran joined the Natural History Museum, Tribhuvan University as a curator in 1975, where he was responsible for collection and preservation of fauna. He has contributed large number of bird specimens to the Natural History Museum. In 1978, he left the museum and started to work as a free-lance ornithologists. Mr. Nepali has worked in several expedition with foreign scientists; R. L. Fleming (1964-1965), C.O. Messer (1966-1967), Dr. J. Martens (1973), Dr. H. Morioka (1980), Dr. Kazuo Wada (1984), Daniel Taylor (1984), etc. to explore birdlife of Nepal. As an ornithologist, he made significant contributions to several inter-disciplinary research projects and expeditions.

In addition to field level exploration, Hari Saran Nepali was very active in conservation of birdlife of Nepal, he was founding president of the Nepal Bird Watching Club in 1982, bringing together professionals and amateurs together. Latter the organization is known as Bird Conservation Nepal $(\mathrm{BCN})$ and active in monitoring and conservation of bird and biodiversity of Nepal. Now this He was member of member of National Committee, International Union for Nature Resources (IUCN) on education; member, Environment Protection Council; member of Oriental Birds Club, UK and representative from Nepal to International Council for Bird Preservation (ICBP), UK.

Regardless of all these activities, Hari Saran Nepali published few scientific articles, numerous popular articles and research reports on fauna with many coauthors. Furthermore, he gave numerous popular talks and was always available for any requests of the media.

Hari Saran Nepali has devoted his life to collect, study and conservation of birds of Nepal. His intellect, enthusiasm, and passion combined to make him an exceptional naturalist. Hari Saran made huge contributions to our understanding of birdlife. With his departure he leaves behind the legacy of dedicated hard work and mentoring of the younger generation biologists. We believe that the life and work of Hari Saran Nepali will inspire many students to carry out work on bird research and conservation. The zoological fraternity of Nepal will miss the physical presence of Hari Saran Nepali and prays that his soul rests in eternal peace. 